которая выражает чувство признательности собеседнику в ответ на его действия [5, c.197].

(7)'It's yours to keep, and wear. A gift.'

'Thank you,' says Tarquin. 'I'm . .. very grateful [6, c. 146].

(- Это подарок, носи на здоровье.

— Спасибо, - говорит Таркин, — я... я очень благодарен тебе).

Здесь стратегия благодарности выражена с помощью фиксированной формы thank you и усилена благодаря использованию сочетания «интенсификатор + прилагательное» very grateful, а также наличию паузы для повышения экспрессивности высказывания.

Таким образом, стратегии недооценки и переоценки позволяют проявить сдержанность, скромность, выразить позитивное отношение к собеседнику, а также поддержать бесконфликтное и гармоничное общение, что отражает культурные и национальные особенности британского характера. Анализ стратегий недооценки и переоценки в речи современных англичан показал, что представители британской лингвокультуры достаточно часто реализуют эти языковые категории в целях соблюдения основных принципов вежливости.

$$
* * *
$$

1. Азарова Л.В. Лексические средства выражения некатегоричности высказываний / Л.В. Азарова // Системное описание лексики германских языков. - Л.: Изд-во Ленингр. ун-та, 1985. Вып. 5. С. 137-142.

2. Власова Е.В. Социолингвистический аспект изучения недооценки и переоценки в речи современного англичанина: на материале художественных произведений начала XXI в.: дис. ... канд. филол. наук / Е.В. Власова - Волгоград, 2005. — 170 с.

3. Власова Е.В. Ритуализированные стратегии недооценки и переоценки в речи современных англичан / Е.В. Власова // Известия Волгоградского государственного педагогического университета. — 2020. — №1 (144). — С. 216-220.

4. Власова Е.В. Коммуникативные средства выражения недооценки. Поведенческий аспект / Е. В. Власова. - Текст: непосредственный // Известия Волгоградского государственного педагогического университета. — 2020. — №3 (146). — С. 136-140.

5. Ларина Т. В. Категория вежливости и стиль коммуникации: сопоставление английских и русских лингвокультурных традиций / Т. В. Ларина. - М.: Рукописные памятники Древней Руси, 2009. $-287 \mathrm{c}$.

6. Kinsella Sophie. Shopaholic abroad / Sophie Kinsella. — Random house, 2012. — 349 c.

7. Leech G.N. Principles of Pragmatics / G. N. Leech. — London, NY: Longman, 1983.

\title{
Шевченко Е.И., Кривошеева Е.И. \\ Особенности перевода описательной документации по строительству и эксплуатации ветряных электростанций с японского на русский язык
}

Тихоокеанский государственный университет

(Россия, Хабаровск)

doi: 10.18411/lj-05-2021-284

\section{Аннотация}

В статье рассматриваются лексические, грамматические и синтаксические особенности текстов по теме строительства и эксплуатации ветряных электростанций на японском языке. Исследуются способы образования терминологии и описываются заимствованные сокращения для обозначения технических деталей и специфики процессов. На материале оригинальной документации, анализируются и предлагаются к использованию наиболее эффективные способы перевода документации в рамках указанной темы с японского на русский язык.

Ключевые слова: ветряная электростанция, перевод, трансформации, японский язык, русский язык. 


\section{Abstract}

The article discusses lexical, grammatical and syntactic features of the texts on the topic of construction and operation of wind power plants in the Japanese language. Methods of terminology formation are investigated and borrowed abbreviations are described to denote technical details and the specifics of certain processes. The most effective ways of translating documentation from Japanese into Russian in regards of construction and operation of wind power plants are analyzed and proposed for use.

Key words: wind power plant, translation, translating method, Japanese, Russian.

Сотрудничество Японии и России в сфере возобновляемых и невозобновляемых источников энергии имеет обширную историю и географию. Современное состояние разбалансированной энергетической отрасли Японии, высокие затраты на энергоресурсы и их нехватка обуславливают повышенный интерес к российским энергоносителям. Так, в 2015 году усилиями японской стороны с целью увеличения количества ветряных электростанций (здесь и далее - ВЭС) были введены в эксплуатацию три ветровые турбины в Камчатском регионе. К тому же, на ВЭФ (Восточный экономический форум) в 2018 ряд японских компании выразил заинтересованность в строительстве 2-го арктического ветропарка в России [2].

Тема представляется актуальной в трех плоскостях. Во-первых, российские населенные пункты с изолированным электроснабжением заинтересованы в снижении тарифов на бытовую электроэнергию, что и является приоритетной задачей ветряной электростанции. Во-вторых, распространение такого типа энергоресурсов позволит России сделать добычу энергии более экологичной, тем самым, реализуя программу Парижского соглашения по сдерживанию изменений климата [3]. В третьих, это является еще одним гарантом обширных инвестиций в российскую экономику со стороны не только одной Японии, но и других стран АТР.

В данной статье рассматриваются стилистические, лексические и синтаксические особенности и приемы перевода технических текстов энергетической направленности с японского на русский язык. Особое внимание уделяется терминологии, относящейся к сфере ветряной природной электроэнергии. Предпринимается попытка обобщить и систематизировать переводческие трансформации, применяемые в исследуемых текстах.

В качестве материала для исследования были использованы работы Института Возобновляемой Энергии, Российской Ассоциации Ветроиндустрии, и Статья «CONSTRUCTION OF WIND TURBINES IN KAMCHATKA».

Прежде всего хотелось бы обратить внимание на перевод специфической лексики. Группа заимствованных слов, в частности англицизмов, не представляет особой сложности при переводе. В основном их используют для названий конкретных частей механизма ветряной электростанции. Однако, особого внимания требует перевод многокомпонентных терминов, например 夕ワ-頂部 «верхушка мачты». При описании частей ВЭС используется специфический термин «мачта» [5]. Прямой перевод заимствования 夕ワ- как башня (tower) неуместен.

Рассмотрим особенности технического перевода на примере синтаксических связей в предложении.

架設システムのフレームを中型クレーンを使用しての設置および補助ワイヤの配置[4]。Paзм ещзение вспомогательных проводов при помощи установки каркаса монтажной системы посредством среднеразмерного крана. В данном примере мы видим двойное употребление падежа を, который определяет сразу две части предложения: 架設システムのフレーム- каркас монтажной системы и中型クレーン «среднеразмерный 
кран». Здесь уместно применить прием логической синонимии. Оба определения относятся к одному глаголуおよび «посредством», но требуют последовательного упоминания, поэтому следует перевести его в первом случае как «при помощи», а во втором - «посредством». Благодаря этому удастся избежать ненужных повторений.

このような施工条件下で，第 1 期施工では $200 t$ 吊りク レーンを搬入して風車 1 基の架設を行った[4]。B данных условиях, на первом этапе строительства был доставлен подвесной кран грузоподъемностью 200 тонн и смонтирована одна ветряная турбина. На данном примере мы можем увидеть, что глагол 行った «проводилось» и существительное 架設 «установка», в исходном предложении образуют словосочетание “проводилась установка". Однако при переводе был применен прием модуляции, позволивший сократить данное сочетание до глагола “смонтировать”. Распространенный характер японских предложений часто требует от переводчика умения ёмко выражать значения того или иного слова; стараться нивелировать излишнюю тавтологию.

豊富な風力・太陽光発電の適地を有するロシア極東でも、同様のやり方で自然エネルギ 一導入 量を伸ばしていくことはできるのだろうか [5]。

Можно ли таким же образом увеличить количество возобновляемых источников энергии, внедряемых на Дальнем Востоке России, где есть множество подходящих площуадок для производства энергии ветра и солнща?

В данном предложении мы видим, что определинием здесь выступает 適地を有する «имеющий подходящие места», а определяемым - ロシア極東 «российский Дальний Восток». При таком переводе первая часть предложения будет перегружена, поэтому в данной ситуации лучшим решением будет перевести его на русский язык в виде сложноподчиненного предложения - «на Дальнем Востоке России, где есть множество подходящих площадок для производства».

2018 年現在、ロシアで比較的大きな発電設備容量を保有する企業にEvrosibenergo (19.5GW)、 E.On（約 11.3GW)、Enel（約 9.4GW）などの民間企業もある [4]。Пo состоянию на 2018 год среди компаний с относительно большой установленной мощностью в России также есть частные компании, такие как Евросибэнерго (19,5 ГВm), E.On (около 11,3 ГВm) и Enel (около 9,4 ГВm). В этом предложении использован прием опущения, так как сочетание 容量を保有する企業в дословном переводе будет звучать как «обладающие... установленной мощностью». В окончательном варианте глагол保有するполностью отсутствует, а его смысловую функцию выполняет союз «с».

この地理上、制度上の特徵をふまえ、ロシア極東での自然エネルギープロジェクトは大きく

分 けて二つの方式で進められている [5]。Исходя из этой географической $и$ институциональной особенности, проекты в области возобновляемых источников энергии на Дальнем Востоке России продвигаются по двум основным направлениям. В конце этого предложения сочетание大きく分けて二つの方式подвергается трансформации модуляции, другими словами, смыслового развития. Прилагательное 大きい, от которого впоследствии образовано наречие, можно перевести по-разному, в зависимости от контекста. Определяемый им глагол 分ける относится к сочетанию二つの方式 «два направления». При переводе на русский язык сочетание 
大きく分けて сливается в одно единственное прилагательное - «основной». В нем и консолидируется смысловое содержание двух японских слов.

横取り装置によるナセルの横移動，降下および所定位置への設置[5]。Поперечная

транспортировка, спуск и установка гондоль в нужное положение с помощью траверса. В этом предложении применена такая трансформация, как конкретизация. Специализированный строительный термин «траверс» заменяет расплывчатое понятие 横取り装置 «устройство захвата» в исходном тексте. Этот факт подтверждает необходимость наличия у переводчика не только узкопрофильных знаний по затрагиваемой теме, но по меньшей мере доступа к соответствующему словарю для предотвращения лексических ошибок.

Таким образом, исходя из перечисленных выше трансформаций, мы можем сделать вывод, что наиболее часто встречаются такие переводческие приемы, как конкретизация и опущения. Безусловно, большую роль играет тип текста, а также его направленность. Сфера ветряных электростанций на данный момент достаточно мало изучена, и для наиболее полной передачи смысла того или иного предложения необходимо прибегать к различным сокращениям и лаконичным формулировкам [1]. Это позволяет упростить восприятие материала и помочь даже тем, кто не имеет профессионального представления о сути предмета.

$$
* * *
$$

1. Кутафьева Н.В /Японский язык. Особенности научно-технического стиля// -М.: Восток- Запад, $2005-136 \mathrm{c}$

2. Развитие ветроэнергетики в России [Электронный ресурс]: режим доступа http://www.fortum.ru (дата обращения: 12.01.2021)

3. Сунгуров Г.Р. /Обзор текущего состояния и перспектив развития сотрудничества России и Японии в области энергетики// журнал «Инновации и Инвестиции» - №3. - 2018

4. 尾松亮/ロシアにおける自然エネルギー活用の展望/ - 自然エネルギー財団上級研究員[Электронный pecypc]: Режим доступа https://www.renewableei.org/pdfdownload/activities/ColumnReport_REinRussia.pdf (дата обращения 20.01.2021).

5. 山本 佳宏 , 岩井 憲一/ カムチャツカ風車工事CONSTRUCTION OF WIND TURBINES IN KAMCHATKA (RUSSIA)/ 駒井ハルテック技報 -Vol.7 - 2017 